\title{
The Influence of Tube Potential on Periodontal Bone Level Measurements and Subjective Image Quality Using a Digital Photostimulable Storage Phosphor Sensor
}

\author{
Bart Vandenberghe ${ }^{1}$, Reinhilde Jacobs ${ }^{1}$ \\ ${ }^{1}$ Oral Imaging Center, Department of Dentistry, Oral Pathology and Maxillofacial Surgery, Faculty of Medicine, Catholic \\ University of Leuven, Leuven, Belgium
}

\author{
Corresponding Author: \\ Reinhilde Jacobs \\ Oral Imaging Centre \\ Katholieke Universiteit Leuven \\ Kapucijnenvoer 7 \\ BE-3000, Leuven \\ Belgium \\ E-mail: reinhilde.jacobs@uzleuven.be
}

\begin{abstract}
Objectives: The purpose of the present study was to determine the measurement accuracy and subjective image quality for periodontal disease diagnosis when using two X-ray tube voltages with a digital photostimulable storage phosphor sensor. Material and Methods: A digital photostimulable storage phosphor (PSP) sensor (Vistascan) and a multipulse X-ray generator (Prostyle Intra) with two tube voltages were used in this study. The front, premolar and molar region of two adult human cadaver skulls jaws were imaged using the X-ray tube at $63 \mathrm{kV}$ and $70 \mathrm{kV}$, both at $8 \mathrm{~mA}$ and decreasing exposure times $(160 \mathrm{~ms}, 120 \mathrm{~ms}$ and $80 \mathrm{~ms})$. A standardized exposure protocol containing waxed occlusal keys and an aiming device ensured proper and reproducible beam alignment. Three observers assessed the digital radiographs for 31 selected periodontal bone loss sites. Radiographic measurements were compared to physical measurements (Standard). Subjective ratings of lamina dura, crater defect and furcation involvement visibility, contrast perception and bone quality were also performed.

Results: Multiple regression equation of the variables $\mathrm{kV}$ and exposure time demonstrated no significant difference for the periodontal bone level measurements $(\mathrm{P}>0.05)$. In $90.3 \%$ and $96.7 \%$ of the measurements for $70 \mathrm{kV}$ and $63 \mathrm{kV}$ respectively, deviation was within $1 \mathrm{~mm}$. The subjective ratings produced similar findings in terms of image quality for both tube voltages and the three exposure times.

Conclusions: The results of the present study revealed that tube voltages of $63 \mathrm{kV}$ and $70 \mathrm{kV}$ provided similar accuracy and image quality for periodontal disease diagnosis.
\end{abstract}

Keywords: dental digital radiography; radiographic image enhancement; radiographic phantom; alveolar process; periodontal diseases; furcation defects.

Accepted for publication: 18 December 2009

To cite this article:

Vandenberghe B, Jacobs R. The Influence of Tube Potential on Periodontal Bone Level Measurements and Subjective Image Quality Using a Digital Photostimulable Storage Phosphor Sensor.

J Oral Maxillofac Res 2010 (Jan-Mar);1(1):e5

URL: http://www.ejomr.org/JOMR/archives/2010/1/e5/e5ht.pdf

doi:10.5037/jomr.2010.1105 


\section{INTRODUCTION}

Intraoral radiographs are often a necessary adjunct in the diagnosis of periodontal diseases regarding extent estimation of alveolar bone loss and visualization of important structures like periodontal ligament space, lamina dura or trabecular pattern [1-3]. However, the outcome of this radiographic evaluation is not only depending on exposure parameters but also on image sensor type and viewing conditions [4-14]. Accuracy of alveolar bone level measurements on conventional or digital radiographs has been found to lie within 1 to $2 \mathrm{~mm}$ deviation [15-17], the latter resulting in similar [17-19] or greater accuracy [20-22]. This discrepancy in literature is most likely due to the many variables in the radiographic chain, the limited standardization of previous studies and the continuously improving technology. Only one of these studies actually investigated a range of exposure times for alveolar bone level measurements [18]. In addition, no studies could be found investigating beam energy on periodontal bone measurements. These factors are crucial though since they directly influence radiographic contrast $[23,24]$. For dental caries diagnosis, Svenson and Petersson [25] have demonstrated no significant difference in diagnostic accuracy between premolars and molars using conventional films exposed at varying tube voltages, although accuracy increased for molars at higher kilovoltage $(\mathrm{kV})$. Similarly, the alveolar crest and the associated accuracy of alveolar bone level measurements may be influenced by different tube voltages since the thickness of the alveolar crest is variable and often affected by small changes in mineral bone density. Furthermore, when considering possible dose savings especially when using digital sensors, laboratory studies have suggested acceptable image quality at a wide range of $\mathrm{kV}$ settings [26-28].

The purpose of the present study was to investigate the possible influence of two different tube voltages on the measurement accuracy of alveolar bone levels using a digital photostimulable storage phosphor system (intraoral digital phosphor plates).

\section{MATERIAL AND METHODS}

Two human cadaver skulls containing multiple bone loss sites (including irregular crater patterns) were obtained with permission from the Department of Anatomy (Catholic University of Leuven, Leuven, Belgium) and selected for this study. The first skull was obtained from an adult cadaver head with soft tissues, both upper and lower cadaver jaw were fixed in a $10 \%$ formalin solution. The second subject used was a dry adult skull covered with custom-made soft tissue simulation. The latter consisted of melted paraffin wax, Mix D, having similar attenuation properties to human soft tissues [29], and which was modelled over the maxilla and mandible. For alveolar bone level assessments, measurements from the cemento-enamel junction (CEJ) to the alveolar crest were chosen for the cadaver jaws, but gutta percha fiducials were glued onto the dry skull's teeth since dehydration of the CEJ could increase observer errors in identifying the measurement landmark. Small fragments with a central indentation were thus glued onto the labial and palatal/ lingual surfaces of the teeth so their end- or midpoints could be used for mesial and distal or central bone level measurements (Figure 1). Physical measurements of the alveolar bone levels around each subject's teeth (mesial and distal, both oral and buccal) were obtained by two observers (department of oral imaging) using a digital sliding calliper (Mitutoyo, Hants, UK) at the nearest $0.01 \mathrm{~mm}$ accuracy. This was done prior to soft tissue

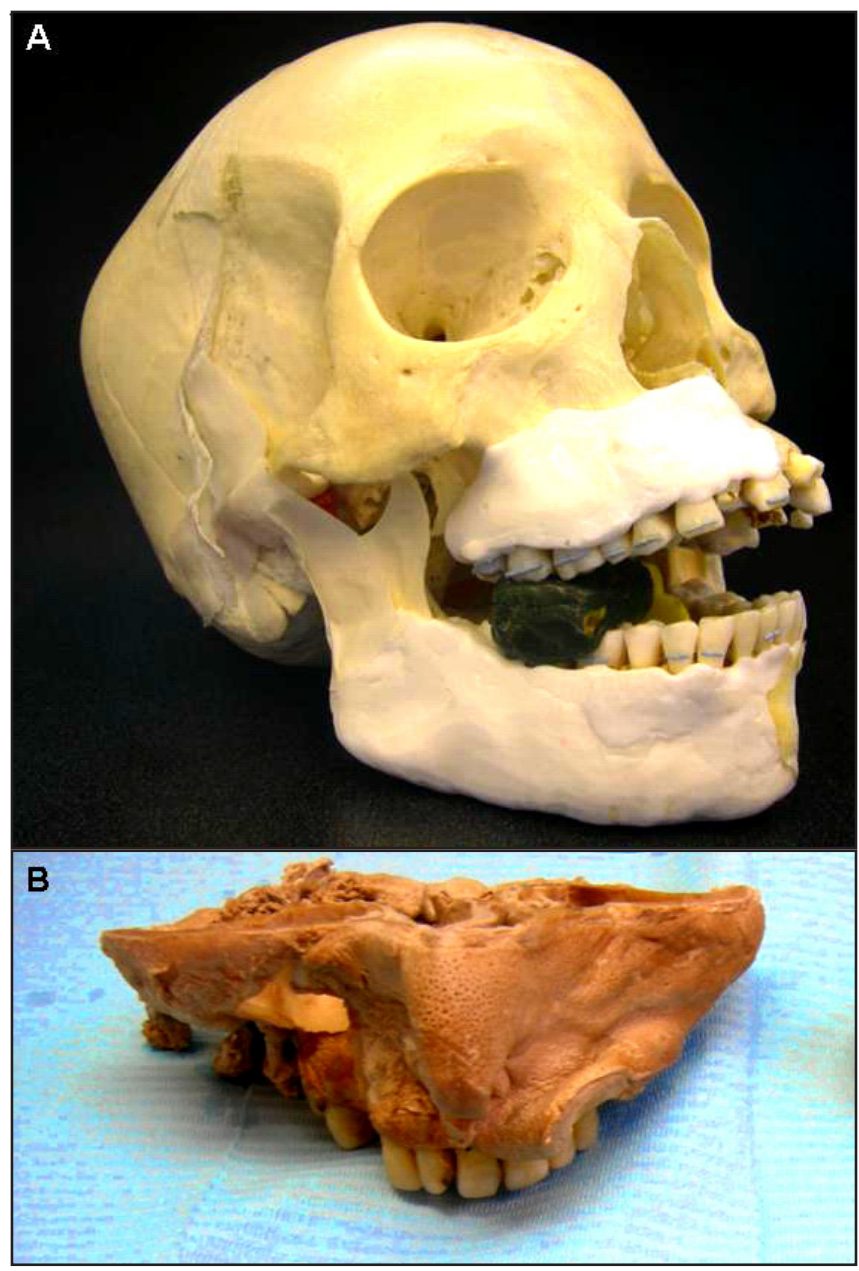

Figure 1. (A) Radiographic protocol of the dry adult skull. The soft tissues were simulated with synthetic material (in white), bone loss fiducials were introduced made from gutta percha fragments and rigid occlusal imprints ensured radiographic reproducibility. (B) Maxillary cadaver jaw with formalin fixed tissues. 
simulation and radiographic exposure for the dry skull, but after radiographic exposure and flap surgery for the cadaver jaws. The observer's averaged measurements could then function as the standard (Standard) for the radiographic evaluations.

Standardized periapical radiographs were made using a photostimulable storage phosphor (PSP) sensor (Vistascan, Dürr Dental GmbH, BietigheimBissingen, Germany) and a multipulse X-ray generator (Prostyle Intra, Planmeca Oy, Helsinki, Finland) at two different $\mathrm{kV}$ settings (63 and $70 \mathrm{kV}), 8 \mathrm{~mA}$, decreasing exposure times $(160 \mathrm{~ms}, 120 \mathrm{~ms}$ and $80 \mathrm{~ms})$ and $30 \mathrm{~cm}$ focal-film distance. Reproducible projection geometry was ensured by utilizing the paralleling technique with aiming devices and bite blocks (XCP, RINN Corporation, Elgin, IL, USA) individualized with waxed imprints of the teeth. For each jaw region (front-premolar-molar), the bite blocks were covered with heated green thermoplastic impression compound (Green Sticks, Kerr Corporation, Orange, CA, USA) for imprinting of the occlusal patterns. A mechanically interlocking rectangular $(4 \mathrm{~cm} \times 3 \mathrm{~cm})$ collimator (Universal Collimator, RINN Corporation, Illinois, USA) was mounted onto the tube end. A total of 72 radiographs (3 exposure times x $2 \mathrm{kV}$ settings $\mathrm{x} 12$

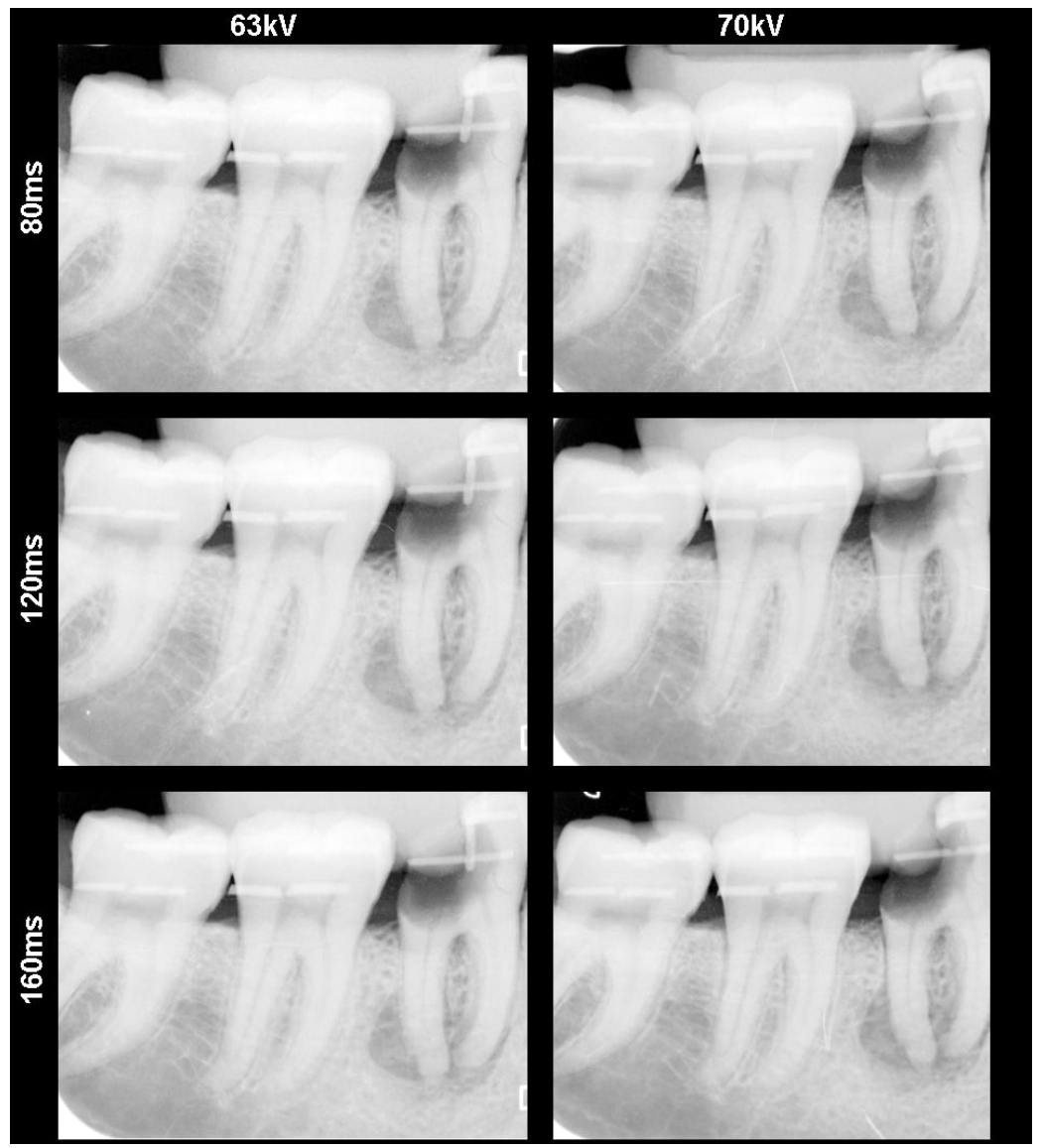

Figure 2. Standardized PSP radiographs of the dry skull's mandibular molar region. The images were obtained using two different tube voltages, $63 \mathrm{kV}$ and $70 \mathrm{kV}$, at decreasing exposure times. periapical skull regions) were thus obtained from the skull jaws for this study. Imaging plates were read out using the Vistascan laser scanner at high resolution $(20 \mathrm{lp} / \mathrm{mm})$, erased using the strong illumination unit, and exported in Tagged Image File Format (TIFF) for randomization and evaluation with Emago advanced, V.3.5.2. image analysis software (Oral Diagnostic Systems, Amsterdam, Netherlands). An example of the radiographic set-up is given in Figure 2.

Thirty-two periodontal bone loss sites, including infrabony defects and furcation involvements, were chosen for the radiographic measurements and assessed by three observers specialized in oral imaging, after three calibration sessions. Alveolar levels were measured with the software tools to the nearest $0.1 \mathrm{~mm}$, in a room with reduced ambient light, on three 17-inch LCD monitors having antireflective layers and same screen resolution (1440 x 900 pixels). Contrast and brightness settings were set to similar percentages. No image enhancement tools were allowed to adjust the images. Furthermore, the observers were asked to provide subjective ratings of following periapical radiographs evaluation parameters: lamina dura delineation, trabecular pattern depiction, contrast perception and crater and furcation involvement visibility, using an ordinal scale from 0 to $3(1=$ bad, $2=$ medium, $3=\operatorname{good}, 0=$ not possible to properly evaluate the variable).

\section{Statistical analysis}

In total, 192 radiographic measurements per observer were compared to the Standard. A $15 \%$ repeat of measurements $(n=32)$ was done at a 1 week interval. Measurement consistency between and within observers was determined. The absolute differences (radiographic measures - physical measures as Standard) from the three observers were then averaged for further analysis. Multiple regression analysis of the dependent variable periodontal bone measurement and independent variables $\mathrm{kV}$ and exposure time was carried out at a significance level of $5 \%$. For the subjective measurements, non parametric statistics were used given the ordinal nature of the data. The variables $\mathrm{kV}$ and exposure time were analyzed by a Friedman ANOVA test. All statistical analyses were carried out using SPSS V.13.0. statistical software (SPSS Inc., Chicago, IL, USA) and MedCalc v.9.3.2 (MedCalc Software bvba, Mariakerke, Belgium). 


\section{RESULTS}

\section{Measurement accuracy}

Inter-observer consistency of the 192 periodontal bone measurements was determined and the reliability analysis demonstrated an intraclass correlation coefficient (ICC) of 0.96 (95\% confidence interval $(\mathrm{CI})$ with 0.95 and 0.97 as upper and lower bound respectively). Since high correlation was found, the measurements between observers could be averaged for further analysis. No intra-observer effect was found when comparing the $15 \%$ repeat of measurements (ICC $=0.96,0.91-0.98$ at 95\% CI).

Table 1 shows the descriptive statistics of the absolute differences from the Standard for the different variables. Measurement deviations ranged from 0.00 to $2.00 \mathrm{~mm}$ from the Standard. The standard deviation (SD) for all variables was found to be consistent. The bar chart of the absolute differences in Figure 3 revealed a similar pattern for both $\mathrm{kVs}$ and although mean deviations seemed to decrease at rising exposure time, this effect was only minimal since the mean's range was smaller than 0.1 $\mathrm{mm}$.

The multiple regression equation revealed no significant influence of the independent variables $\mathrm{kV}$ (63 and 70) $(\mathrm{P}=0.92)$ and exposure time $(80 \mathrm{~ms}, 120 \mathrm{~ms}$, $160 \mathrm{~ms})(\mathrm{P}=0.38)$ on the periodontal bone measurements at a significance level of $5 \%$. When ignoring exposure time, $90.3 \%$ of the $70 \mathrm{kV}$ measurements and $96.8 \%$ of the $63 \mathrm{kV}$ ones were within a clinically acceptable threshold level of $1 \mathrm{~mm}$ deviation (see Figure 4). When reducing the clinical threshold to $0.5 \mathrm{~mm}, 66.1 \%$ for $70 \mathrm{kV}$ and $66.7 \%$ for $63 \mathrm{kV}$ were found to be within this limit. Although no significant difference was found between the two $\mathrm{kV}$ settings, the curve in Figure 4 increases slightly faster for $63 \mathrm{kV}$, indicating higher but insignificant accuracy.

\section{Subjective quality evaluation}

The results of the Friedman ANOVA test are presented in Table 2. The 6 groups compared were the combinations of

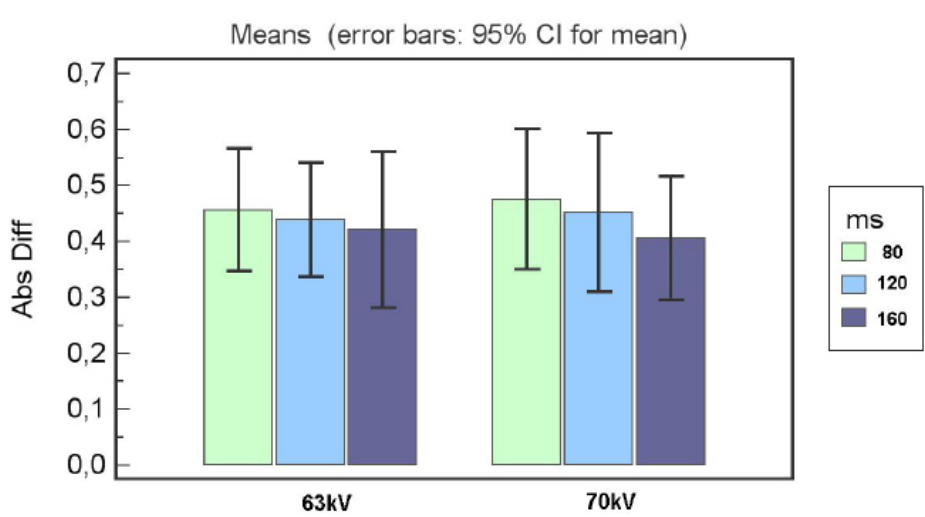

Figure 3. Bar chart for the absolute differences (abs diff in mm, y-axis) of the radiographic measurements from the Standard. The means and error bars at a $95 \%$ confidence interval (CI) are shown for the different exposure times (ms), clustered by the two $\mathrm{kV}$ settings (x-axis).

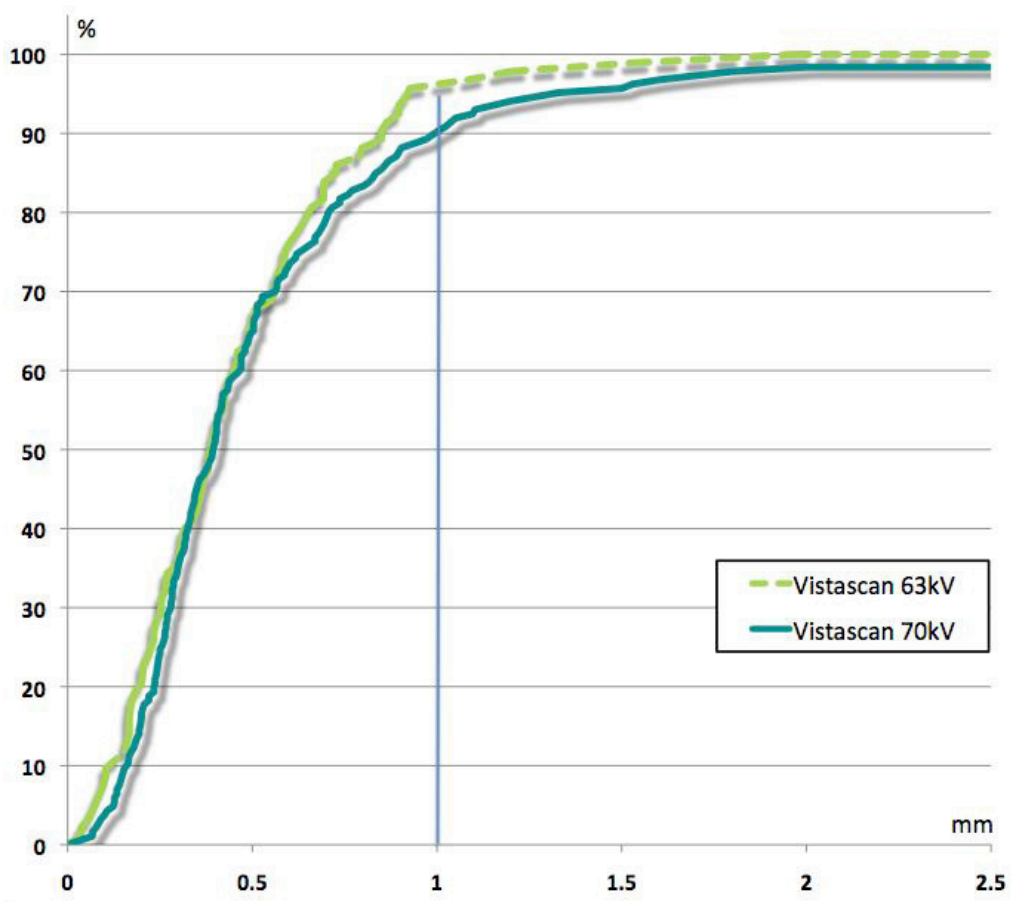

Figure 4. Percentage of measurements (y-axis) falling within a specific distance from the Standard (x-axis), ignoring exposure time. At least $90 \%$ of measurements were $1 \mathrm{~mm}$ deviation. A $\mathrm{kV}$ of 63 resulted in a slightly higher accuracy at this threshold level.

Table 1. Descriptive statistics of the periodontal bone level measurements ${ }^{\mathrm{a}}$ for the variables $\mathrm{kV}$ (irrespective exposure time) and exposure time (irrespective $\mathrm{kV}$ )

\begin{tabular}{lccccc}
\hline \multirow{2}{*}{ Descriptives } & \multicolumn{2}{c}{ Variables kV } & \multicolumn{3}{c}{ Exposure time } \\
\cline { 2 - 6 } & $\mathbf{k V ~ 6 3}$ & $\mathbf{k V ~ 7 0}$ & $\mathbf{8 0 ~} \mathbf{~ s}$ & $\mathbf{1 2 0} \mathbf{~ m s}$ & $\mathbf{1 6 0 ~} \mathbf{~ m s}$ \\
\hline Sample size & 96 & 96 & 64 & 64 & 64 \\
Minimum & 0.00 & 0.00 & 0.00 & 0.00 & 0.00 \\
Maximum & 1.97 & 2.00 & 1.80 & 2.00 & 1.97 \\
Mean & 0.44 & 0.44 & 0.47 & 0.45 & 0.41 \\
95\% CI & $0.37-0.51$ & $0.37-0.52$ & $0.39-0.54$ & $0.36-0.53$ & $0.33-0.50$ \\
SD & 0.33 & 0.35 & 0.32 & 0.34 & 0.35 \\
\hline
\end{tabular}

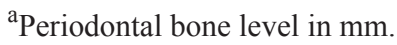

$\mathrm{CI}=$ confidence interval of the mean; $\mathrm{SD}=$ standard deviation. 
Table 2. Results of the Friedman ANOVA test for the ordinal scale ratings, established for the periapical radiographs evaluation parameters visibility in the six different groups ${ }^{\mathrm{a}}$

\begin{tabular}{|c|c|c|c|c|c|c|c|c|c|c|}
\hline \multirow{2}{*}{ Parameters } & \multicolumn{6}{|c|}{ Ordinal scale ratings (mean rank) in six groups } & \multirow{2}{*}{$\mathbf{N}$} & \multirow{2}{*}{ Chi-Square } & \multirow{2}{*}{ Df } & \multirow{2}{*}{$\mathbf{P}^{\mathbf{b}}$ value } \\
\hline & 1 & 2 & 3 & 4 & 5 & 6 & & & & \\
\hline Lamina dura delineation & 3.08 & 3.58 & 3.58 & 3.58 & 3.58 & 3.58 & 6 & 5.00 & 5 & $0.42^{\mathrm{c}}$ \\
\hline Trabecular pattern depiction & 2.33 & 3.25 & 3.25 & 3.75 & 3.75 & 4.67 & 6 & 8.63 & 5 & $0.13^{\mathrm{c}}$ \\
\hline Contrast perception & 3.00 & 3.00 & 3.00 & 3.50 & 4.50 & 4.00 & 6 & 7.50 & 5 & $0.19^{c}$ \\
\hline Bone crater involvement & 3.33 & 3.33 & 3.33 & 3.33 & 3.83 & 3.83 & 6 & 1.11 & 5 & $0.95^{\mathrm{c}}$ \\
\hline Furcation defect involvement & 2.83 & 2.33 & 3.83 & 3.33 & 4.33 & 4.33 & 6 & 8.00 & 5 & $0.16^{\mathrm{c}}$ \\
\hline
\end{tabular}

${ }^{\mathrm{a}} \mathrm{Six}$ groups are combination of two $\mathrm{kV}$ settings and three exposure times: $1=70 \mathrm{kV}, 80 \mathrm{~ms} ; 2=63, \mathrm{kV} 80 \mathrm{~ms} ; 3=70 \mathrm{kV}, 120 \mathrm{~ms} ; 4=$ $63 \mathrm{kV}, 120 \mathrm{~ms} ; 5=70 \mathrm{kV}, 160 \mathrm{~ms} ; 6=63 \mathrm{kV}, 160 \mathrm{~ms}$.

${ }^{\mathrm{b}}$ Tested between the groups.

${ }^{\mathrm{c}}$ The mean differences are not significant at $95 \%$ significance level.

$\mathrm{Df}=$ degree of freedom.

the two $\mathrm{kV}$ settings ( 63 and $70 \mathrm{kV}$ ) with the three exposure times (80, 120 and $160 \mathrm{~ms}$ ). No significant differences were found for the subjective ratings of lamina dura delineation $(\mathrm{P}=0.42)$ or trabecular pattern visibility $(\mathrm{P}=0.13)$, contrast perception $(\mathrm{P}=0.19)$, crater $(\mathrm{P}=0.95)$ and furcation $(\mathrm{P}=0.16)$ involvement visibility using the different $\mathrm{kV}$ or exposure time settings. The bar chart from the ordinal scores of the trabecular pattern depiction variable (see Figure 5) did reveal higher scores at rising exposure times, although this was found to be insignificant. The same applies for the $\mathrm{kV}$ setting of 63 compared to $70 \mathrm{kV}$. All other variables had similar bar charts.

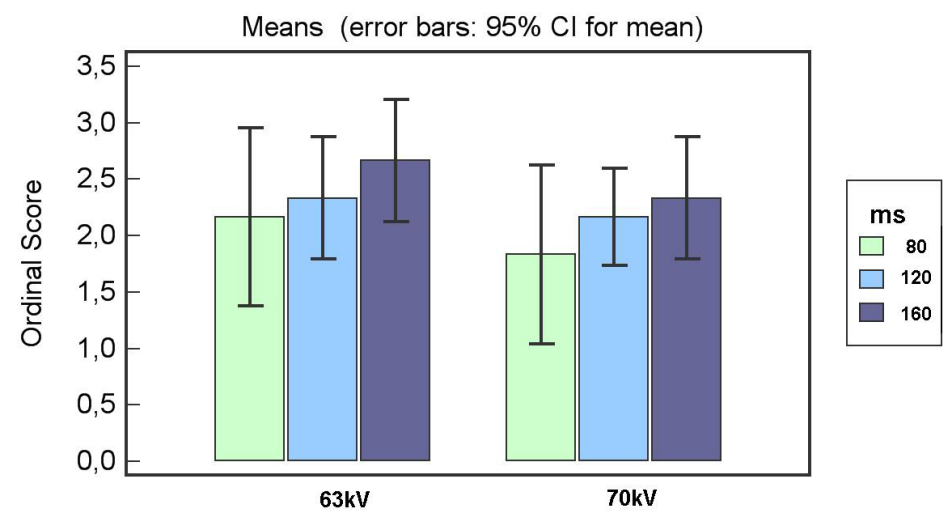

Figure 5. Bar chart for the subjective quality ratings of trabecular pattern depiction. Ordinal scores of the observers (y-axis) are plotted by exposure times (ms) and clustered by $\mathrm{kV}$ (x-axis).

\section{DISCUSSION}

The main objective in this study was to determine the influence of two $\mathrm{kV}$ settings $(63 \mathrm{kV}$ and $70 \mathrm{kV})$ on periodontal bone level measurement accuracy using a digital PSP sensor. Furthermore, since exposure time directly affects radiographic contrast, a small range of exposure times was used to investigate this influence.

The results of the present study revealed that no significant difference was found for the two $\mathrm{kV}$ settings, and neither for the different exposure times. Although no other studies have compared $\mathrm{kV}$ settings for alveolar bone measurement accuracy, our findings confirm certain laboratory studies on different tube voltages [26-28]. These studies however investigated wide $\mathrm{kV}$ ranges for direct digital sensors rather than for PSP sensors, but all conclude that the sensors operate well at various $\mathrm{kV}$ settings with highest contrast at low $\mathrm{kV}$ settings, just like conventional film. But also some in vitro studies have demonstrated similar findings. De Almeida et al. [30], using dry skulls and an aluminium step-wedge-studied the effect of various exposure times

and $\mathrm{kV}$ settings on subjectively rated image quality of four different digital sensors and demonstrated no significant difference between 60 and $70 \mathrm{kV}$ for the PSP system at a wide range of exposure times. Kaeppler et al. [31] also concluded the same for two tube voltages on the visibility of simulated decayed and peri-implant lesions on dry human skulls using a PSP sensor. Both mentioned studies were based on subjective ratings though, but this is similar to our secondary findings, the subjective ratings for lamina dura, trabecular pattern, contrast, crater and furcation involvement visibility, which scored alike for both tube voltages. Our results do suggest a small preference for the $63 \mathrm{kV}$ setting, for both measurement accuracy (defined as bone level measurement from the Standard) and subjective ratings, although this was not significant $(\mathrm{P}>0.05)$. Helmrotet al. [32] found that when using multipulse $X$-ray generators or faster films, degradation of radiographic contrast is seen and may need a 5 to $8 \mathrm{kV}$ decrease for counteracting this phenomenon. Since digital sensors are often more sensitive than conventional films, this may play a role, especially at very low exposure times. Further research is thus needed since the minimal exposure time used in this study was $80 \mathrm{~ms}$. 
Although there may be some confusion on what the clinically acceptable deviation for bone loss measurements may be, it has been reported that 0.5 to $1 \mathrm{~mm}$ deviation should be accomplished when using a correct standardized radiographic set-up [1-3]. When considering a $1 \mathrm{~mm}$ deviation, $90.3 \%$ and $96.8 \%$ of the measurements in this study for respectively 70 and $63 \mathrm{kV}$ fell within this range, which is similar to other studies [15-17]. Also the excellent intra- and inter-observer consistency found were indicative of an adequate measurement method. However, the limitations in this study were the use of a single digital sensor and a limited exposure range. Further studies thus need to be conducted investigating tube voltage influence on measurement accuracy at lower exposure times and using PSP as well as direct digital sensors. Finally, also newer detector technology having higher bit depths, which theoretically would allow higher contrast levels, and/or higher screen resolutions may further improve the accurate depiction of the alveolar crest or other important dental tissues.

\section{CONCLUSIONS}

This study demonstrated no significant difference between radiographic measurements of periodontal bone levels on digital photostimulable storage phosphor radiographs made with two different tube voltages, 63 or $70 \mathrm{kV}$. When decreasing exposure time from $160 \mathrm{~ms}$ to $120 \mathrm{~ms}$ or $80 \mathrm{~ms}$, no significant $(\mathrm{P}>0.05)$ difference between these voltages was either found. For subjective ratings of lamina dura, trabecular pattern, crater and furcation involvement visibility or contrast perception, similar findings were found.

\section{ACKNOWLEDGMENTS AND DISCLOSURE STATEMENTS}

The authors report no conflicts of interest related to this study.

\section{REFERENCES}

1. Mol A. Imaging methods in periodontology. Periodontol 2000. 2004;34:34-48. Review. [Medline: 14717854] [doi: 10.1046/j.0906-6713.2003.003423.x]

2. Tugnait A, Clerehugh V, Hirschmann PN. The usefulness of radiographs in diagnosis and management of periodontal diseases: a review. J Dent. 2000 May;28(4):219-26. Review. [Medline: 10722894] [doi: 10.1016/S0300-5712(99)00062-7]

3. Brägger U. Radiographic parameters: biological significance and clinical use. Periodontol 2000. 2005;39:73-90. Review. [Medline: 16135065] [doi: 10.1111/j.1600-0757.2005.00128.x]

4. Berkhout WE, Beuger DA, Sanderink GC, van der Stelt PF. The dynamic range of digital radiographic systems: dose reduction or risk of overexposure? Dentomaxillofac Radiol. 2004 Jan;33(1):1-5. [Medline: 15140814] [doi: $10.1259 / \mathrm{dmfr} / 40677472$ ]

5. Bhaskaran V, Qualtrough AJ, Rushton VE, Worthington HV, Horner K. A laboratory comparison of three imaging systems for image quality and radiation exposure characteristics. Int Endod J. 2005 Sep;38(9):645-52. [Medline: 16104978] [doi: 10.1111/j.1365-2591.2005.00998.x]

6. Borg E, Attaelmanan A, Gröndahl HG. Subjective image quality of solid-state and photostimulable phosphor systems for digital intra-oral radiography. Dentomaxillofac Radiol. 2000 Mar;29(2):70-5. [Medline: 10808218] [doi: $10.1038 / \mathrm{sj} . \mathrm{dmfr} .4600501]$

7. Pfeiffer P, Schmage P, Nergiz I, Platzer U. Effects of different exposure values on diagnostic accuracy of digital images. Quintessence Int. 2000 Apr;31(4):257-60. [Medline: 11203933]

8. Brettle DS, Workman A, Ellwood RP, Launders JH, Horner K, Davies RM. The imaging performance of a storage phosphor system for dental radiography. Br J Radiol. 1996 Mar;69(819):256-61. [Medline: 8800870] [doi: 10.1259/0007-1285-69-819-256]

9. Borg E, Gröndahl HG. On the dynamic range of different X-ray photon detectors in intra-oral radiography. A comparison of image quality in film, charge-coupled device and storage phosphor systems. Dentomaxillofac Radiol. 1996 Apr;25(2):82-8. [Medline: 9446978 ]

10. Heo MS, Choi DH, Benavides E, Huh KH, Yi WJ, Lee SS, Choi SC. Effect of bit depth and kVp of digital radiography for detection of subtle differences. Oral Surg Oral Med Oral Pathol Oral Radiol Endod. 2009 Aug;108(2):278-83. Epub 2009 Mar 9. [Medline: 19272812] [doi: 10.1016/j.tripleo.2008.12.053]

11. Vandenberghe B, Bud M, Sutanto A, Jacobs R. The use of high-resolution Digital imaging technology for small diameter K-file length determination in endodontics. Clin Oral Investig. 2009 May 19. [Epub ahead of print] [Medline: 19452176] [doi: 10.1007/s00784-009-0285-1]

12. Wenzel A, Haiter-Neto F, Gotfredsen E. Influence of spatial resolution and bit depth on detection of small caries lesions with digital receptors. Oral Surg Oral Med Oral Pathol Oral Radiol Endod. 2007 Mar;103(3):418-22. Epub 2006 Aug 2. [Medline: 17321456] [doi: 10.1016/j.tripleo.2006.05.016] 
13. Heo MS, Han DH, An BM, Huh KH, Yi WJ, Lee SS, Choi SC. Effect of ambient light and bit depth of digital radiograph on observer performance in determination of endodontic file positioning. Oral Surg Oral Med Oral Pathol Oral Radiol Endod. 2008 Feb;105(2):239-44. Epub 2007 Jun 29. [Medline: 17604662] [doi: 10.1016/j.tripleo.2007.02.002]

14. Hellén-Halme K, Petersson A, Warfvinge G, Nilsson M. Effect of ambient light and monitor brightness and contrast settings on the detection of approximal caries in digital radiographs: an in vitro study. Dentomaxillofac Radiol. 2008 Oct;37(7):380-4. [Medline: 18812599] [doi: 10.1259/dmfr/26038913]

15. Pepelassi EA, Diamanti-Kipioti A. Selection of the most accurate method of conventional radiography for the assessment of periodontal osseous destruction. J Clin Periodontol. 1997 Aug;24(8):557-67. [Medline: 9266343] [doi: 10.1111/j.1600-051X.1997.tb00229.x]

16. Eickholz P, Hausmann E. Accuracy of radiographic assessment of interproximal bone loss in intrabony defects using linear measurements. Eur J Oral Sci. 2000 Feb;108(1):70-3. [Medline: 10706480] [doi: 10.1034/j.1600-0722.2000.00729.x]

17. Pecoraro M, Azadivatan-le N, Janal M, Khocht A. Comparison of observer reliability in assessing alveolar bone height on direct digital and conventional radiographs. Dentomaxillofac Radiol. 2005 Sep;34(5):279-84. [Medline: 16120877] [doi: $10.1259 / \mathrm{dmfr} / 13900561]$

18. Gröndahl K, Gröndahl HG. Marginal bone level buccal to mandibular molars in digital radiographs from charge-coupled device and storage phosphor systems. An in vitro study. J Clin Periodontol. 1997 May;24(5):306-12. [Medline: 9178109$]$ [doi: 10.1111/j.1600-051X.1997.tb00762.x]

19. Henriksson CH, Stermer EM, Aass AM, Sandvik L, Møystad A. Comparison of the reproducibility of storage phosphor and film bitewings for assessment of alveolar bone loss. Acta Odontol Scand. 2008;66(6):380-4. [Medline: 18932094] [doi: 10.1080/00016350802438086]

20. Kaeppler G, Vogel A, Axmann-Krcmar D. Intra-oral storage phosphor and conventional radiography in the assessment of alveolar bone structures. Dentomaxillofac Radiol. 2000 Nov;29(6):362-7. [Medline: 11114666] [FREE Full Text] [doi: 10.1038/sj.dmfr.4600556]

21. Li G, Engström PE, Nasström K, Lü ZY, Sanderink G, Welander U. Marginal bone levels measured in film and digital radiographs corrected for attenuation and visual response: an in vivo study. Dentomaxillofac Radiol. 2007 Jan;36(1):7-11. [Medline: 17329581] [doi: 10.1259/dmfr/28315324]

22. Jorgenson T, Masood F, Beckerley JM, Burgin C, Parker DE. Comparison of two imaging modalities: F-speed film and digital images for detection of osseous defects in patients with interdental vertical bone defects. Dentomaxillofac Radiol. 2007 Dec;36(8):500-5. [Medline: 18033948] [doi: 10.1259/dmfr/29704550]

23. Frederiksen NL. Health physics. In: White SC, Pharoah MJ, editors. Oral Radiology. Principles and Interpretation. St Louis: Mosby; 2004. p. 265-77.

24. Curry TS, Dowdey JE, Murry RC. Christensen's physics of diagnostic radiology. Philadelphia: Lea and Febiger; 1990. p. $36-60$.

25. Svenson B, Petersson A. Influence of tube voltage on radiographic diagnosis of caries in premolars and molars. Swed Dent J. 1991;15(5):245-50. [Medline: 1767370]

26. Kitagawa H, Farman AG. Effect of beam energy and filtration on the signal-to-noise ratio of the Dexis intra-oral X-ray detector. Dentomaxillofac Radiol 2004;33:21-24. [doi: 10.1259/dmfr/26493631]

27. Goshima T, Goshima Y, Scarfe WC, Farman AG. Sensitometric response of the Sens-A-Ray, a charge-coupled imaging device, to changes in beam energy. Dentomaxillofac Radiol. 1996 Jan;25(1):17-8. [Medline: 9084280$]$

28. Hayakawa Y, Farman AG, Scarfe WC, Kuroyanagi K, Rumack PM, Schick DB. Optimum exposure ranges for computed dental radiography. Dentomaxillofac Radiol. 1996 Apr;25(2):71-5. [Medline: 9446976]

29. White DR. Phantom materials for photons and electrons. The Hospital Physicists' Association, Radiotherapy Topic Group. Scientific Report Series. 1977;20:1-30.

30. de Almeida SM, de Oliveira AE, Ferreira RI, Bóscolo FN. Image quality in digital radiographic systems. Braz Dent J. 2003;14(2):136-41. [Medline: 12964659] [doi: 10.1590/S0103-64402003000200012]

31. Kaeppler G, Dietz K, Reinert S. Influence of tube potential setting and dose on the visibility of lesions in intraoral radiography. Dentomaxillofac Radiol. 2007 Feb;36(2):75-9. [Medline: 17403883] [doi: 10.1259/dmfr/75743437]

32. Helmrot E, Carlsson GA, Eckerdal O. Effects of contrast equalization on energy imparted to the patient: a comparison of two dental generators and two types of intraoral film. Dentomaxillofac Radiol. 1994 May;23(2):83-90. [Medline: 7835508]

\footnotetext{
To cite this article:

Vandenberghe B, Jacobs R. The Influence of Tube Potential on Periodontal Bone Level Measurements and Subjective Image Quality Using a Digital Photostimulable Storage Phosphor Sensor.

J Oral Maxillofac Res 2010 (Jan-Mar);1(1):e5

URL: http://www.ejomr.org/JOMR/archives/2010/1/e5/e5ht.pdf

doi: $10.5037 /$ jomr.2010.1105
} 
Copyright (C) Vandenberghe B, Jacobs R. Accepted for publication in the JOURNAL OF ORAL \& MAXILLOFACIAL RESEARCH (http://www.ejomr.org)), 18 December 2009.

This is an open-access article, first published in the JOURNAL OF ORAL \& MAXILLOFACIAL RESEARCH, distributed under the terms of the Creative Commons Attribution-Noncommercial-No Derivative Works 3.0 Unported License, which permits unrestricted non-commercial use, distribution, and reproduction in any medium, provided the original work and is properly cited. The copyright, license information and link to the original publication on (http://www.ejomr.org/) must be included. 